\title{
Weed Control in Dicamba-Resistant Soybean with Glyphosate/ Dicamba Applied at Various Doses and Timings
}

\author{
Nader Soltani (D, Christy Shropshire $(D$, and Peter H. Sikkema (iD \\ University of Guelph Ridgetown Campus, Ridgetown, On NOP 2C0, Canada \\ Correspondence should be addressed to Nader Soltani; soltanin@uoguelph.ca
}

Received 2 October 2019; Revised 17 December 2019; Accepted 18 January 2020; Published 12 February 2020

Academic Editor: Daryl Bowman

Copyright (c) 2020 Nader Soltani et al. This is an open access article distributed under the Creative Commons Attribution License, which permits unrestricted use, distribution, and reproduction in any medium, provided the original work is properly cited.

\begin{abstract}
Seven field trials were completed over a three-year period (2016 to 2018) in southwestern Ontario, Canada, to assess weed control in conventional-till dicamba-resistant (DR) soybean with glyphosate/dicamba (2:1 ratio) applied postemergence (POST) at 3 doses $\left(900,1350\right.$, and $1800 \mathrm{~g} \cdot \mathrm{ae} \cdot \mathrm{ha}^{-1}$ ) and 3 application timings (up to 5,15 , and $25 \mathrm{~cm}$ weeds). There was minimal soybean injury $(\leq 2 \%)$ from treatments evaluated. Glyphosate/dicamba applied at application timing of up to 5, 15, and $25 \mathrm{~cm}$ weeds, controlled Amaranthus spp. (pigweed spp.) 87-96, 94-99, and 99\%; Ambrosia artemisiifolia (common ragweed) 93-99, 97-99, and 99-100\%; Chenopodium album (lambsquarters) 89-99, 95-100, and 99-100\%; Echinochloa crus-galli (barnyardgrass) 81-84, 94-96, and 96-97\%; Setaria faberi (giant foxtail) 37-90, 77-98, and 99-100\%; and Setaria viridis (green foxtail) 94-96, 99, and 99-100\%, respectively. Additionally, glyphosate/dicamba applied POST at 900, 1350, and $1800 \mathrm{~g} \cdot \mathrm{ae} \cdot \mathrm{ha}^{-1}$ controlled Amaranthus spp. 90-97, 95-98, and 97-99\%; A. artemisiifolia 95-98, 97-99, and 99-100\%; C. album 92-99, 95-100, and 98-100\%; E. crus-galli 84-88, 9394, and 95-96\%; S. faberi 74-95, 75-97, and 79-98\%; and S. viridis 98, 98-99, and 98-100\%, respectively. Weed interference reduced DR soybean yield as much as $51 \%$ compared to the highest yielding treatments. Results indicate that glyphosate/dicamba applied POST at the label doses can provide an adequate control of troublesome weeds in DR soybean. Weed control was generally most consistent when glyphosate/dicamba was applied at the highest registered dose in Ontario (1800 g.ae.ha $\left.{ }^{-1}\right)$ and when weeds were up to $25 \mathrm{~cm}$ tall.
\end{abstract}

\section{Introduction}

Multiple-herbicide-resistant weeds, especially glyphosateresistant (GR) weed biotypes, have increased rapidly in respect to number of weed species and geographic areas affected over the past 12 years in Ontario. Presently, there are four weed species with confirmed resistance to glyphosate in Ontario, including Conyza canadensis (L.) Cronq. (Canada fleabane), Amaranthus tuberculatus L. (waterhemp), Ambrosia trifida L. (giant ragweed), and Ambrosia artemisiifolia L. (common ragweed) [1-5]. As herbicide-resistant weeds are becoming more prevalent in many parts of North America, new soybean cultivars have been developed with transgenes that provide resistance to both glyphosate and dicamba (Roundup Ready Xtend ${ }^{\circledR}$ ). Dicamba-resistant (DR) soybean has transgenes that provide resistance to glyphosate through an insensitive enolpyruvyl shikimate 3-phosphate synthase (CP4 EPSPS) enzyme and to dicamba through metabolism by dicamba monooxygenase (DMO) [6].

DR soybean will allow soybean growers to incorporate dicamba, a Group 4 benzoic acid herbicide with excellent activity on nearly 100 annual, biennial, and perennial broadleaved weeds, into their cropping system. Despite being in use for more than 50 years, there are only six weed species that are currently confirmed resistant to dicamba worldwide [6, 7]. Dicamba also provides effective control of GR weeds including Amaranthus palmeri L. (palmer amaranth Wats.), A. tuberculatus, A. artemisiifolia, A. trifida, and $C$. canadensis $[1,5,8,9]$.

DR soybean was first introduced in Ontario in 2017, and currently, over $50 \%$ of soybean fields in eastern Canada are seeded to DR soybean cultivars. The current registered dose 
of glyphosate/dicamba (2:1 ratio premix) in DR soybean in Ontario ranges from $900(600+300)$ to $1800(1200+600)$ $\mathrm{g} \cdot \mathrm{ae} \cdot \mathrm{ha}^{-1}[10]$.

Earlier studies have mainly focused on GR weed control with glyphosate/dicamba in DR soybean in Ontario $[1,3-5,9]$. There have been little published data on the effect of glyphosate/dicamba for the control of other troublesome weeds in DR soybean in Ontario. Common problematic weeds in soybean in Ontario include Amaranthus spp. (green and redroot pigweed), A. artemisiifolia, Chenopodium album L. (common lambsquarters), Setaria viridis L. (green foxtail), Setaria faberi Herrm. (giant foxtail), and Echinochloa crus-galli (L.). P. Beauv. (barnyardgrass). The efficacy of glyphosate/dicamba applied postemergence (POST) at various application doses and application timings to control these troublesome weeds in DR soybean is not clear under Ontario environmental conditions. Dicamba, when used in combination with glyphosate in DR soybean, can provide effective broad-spectrum control of these weeds [11]. More research is also required to establish the optimal glyphosate/dicamba application dose when weeds are at different heights.

This research was established to assess control of common annual grass and broadleaved weeds in conventional-till DR soybean with glyphosate/dicamba (2:1 ratio premix) applied POST at three doses (900, 1350, and $1800 \mathrm{~g} \cdot \mathrm{ae} \cdot \mathrm{ha}^{-1}$ ) and three application timings (up to 5, 15, and $25 \mathrm{~cm}$ weeds) in Ontario.

\section{Materials and Methods}

There was a total of seven field experiments which included two experiments (one in 2017 and 2018) at Exeter, ON $\left(43^{\circ}\right.$ $19^{\prime} 1.2108^{\prime \prime} \mathrm{N}, 81^{\circ} 30^{\prime} 3.8736^{\prime \prime} \mathrm{E}$ ), and five experiments (two in 2016, one in 2017, and two in 2018) at Ridgetown, ON $\left(42^{\circ}\right.$ $\left.26^{\prime} 41.46^{\prime \prime} \mathrm{N}, 81^{\circ} 52^{\prime} 44.472^{\prime \prime} \mathrm{W}\right)$. The experiment was arranged as a factorial with four replications and established as a randomized complete block design. Factor one consisted of three glyphosate/dicamba doses (DOSE: 0, 900, 1350, and $1800 \mathrm{~g} \cdot \mathrm{ae} \cdot \mathrm{ha}^{-1}$ ) and the second factor was application timing based on weed height (TIMING: up to 5, 15, and $25 \mathrm{~cm}$ weeds).

Plots were 10 and $8 \mathrm{~m}$ long at Exeter and Ridgetown, respectively, and included four rows (spaced $75 \mathrm{~cm}$ apart) of DR soybean (“DKB 14-41”/“DKB 06-61”/“DKB 12-57”) seeded $4 \mathrm{~cm}$ deep at a seeding rate of $400,000 \mathrm{ha}^{-1}$. Density of weed species present at each evaluation for Ridgetown and Exeter, ON, sites is shown in Table 1. Herbicides were applied using a $\mathrm{CO}_{2}$-pressurized backpack sprayer delivering $200 \mathrm{~L} \cdot \mathrm{ha}^{-1}$ at a pressure of $207 \mathrm{kPa}$. Herbicides were applied when weeds were up to approximately 5, 15, and $25 \mathrm{~cm}$ in height. The boom for the sprayer was $1.5 \mathrm{~m}$ long equipped with four ULD 120-02 (Hypro, New Brighton, Minnesota) nozzles spaced $0.5 \mathrm{~m}$ apart producing a spray width of $2.0 \mathrm{~m}$ (ground level).

Visible injury to DR soybean was assessed on a scale of $0-100(0=$ no injury and $100=$ complete death $)$ at 1 and 4 weeks after herbicide application (WAA). Weed control was evaluated on a $0-100$ scale $(0=$ no control and
$100=$ complete control) at 4 and 8 WAA and 10 weeks after the final herbicide treatment (WAC). DR soybean was harvested at maturity using a small-plot combine. DR soybean seed moisture and yield (13\% adjustment) were then recorded.

The GLIMMIX procedure in SAS [12] was used for data analysis. The experimental design was used to construct the model used; fixed effects were DOSE, TIMING, and the DOSE by TIMING interaction, and random effects were environment, environment by DOSE by TIMING interaction, replicate within environment, the DOSE, and TIMING by replicate within environment interactions. Fit statistics and residual plots were assessed to determine the best distribution and associated link function for each parameter, which was then used to analyze data on the model scale. The normal distribution (identity link) was used for soybean yield, and the same distribution with an arcsine square root transformation was used for percent visible soybean injury and percent visible weed control. The gamma distribution (log link) was used to analyze soybean moisture at harvest. Tukey's adjustment was applied to pairwise comparisons before determining treatment variations at $P<0.05$. The inverse link function or a back-transformation, where necessary, was applied to LSMEANS for presentation on the data scale. The DOSE by TIMING interaction was negligible for all parameters; therefore, only differences for the DOSE and TIMING main effects were determined [13]. The nontreated control, assigned a value of 0 for injury to the crop and weed control assessments, was excluded from the analysis because of no variance; differences between treatment means and the value zero were identified using the LSMEANS output.

\section{Results and Discussion}

3.1. Crop Response. Injury symptoms in soybean included leaf drooping and chlorosis. At 1 WAA, there was minimal visible soybean injury $(<2 \%)$ from the herbicide treatments evaluated (Table 2). Injury was slightly greater when glyphosate/dicamba was applied at late timing (up to $25 \mathrm{~cm}$ tall weeds) compared to the earlier timings (up to 5 or $15 \mathrm{~cm}$ tall weeds). According to Kniss [13] meta-analysis investigating soybean response to dicamba exposure, the likelihood for non-DT soybean injury is higher when the crop is exposed to dicamba at late timing compared to earlier timing. Glyphosate/dicamba applied POST at 1350 and $1800 \mathrm{~g} \cdot \mathrm{ae} \cdot \mathrm{ha}^{-1}$ caused slightly higher DR soybean injury than that at $900 \mathrm{~g} \cdot \mathrm{ae} \cdot \mathrm{ha}^{-1}$.

Soybean seed moisture content was less when glyphosate/dicamba was applied to up to $25 \mathrm{~cm}$ tall weeds compared to when it was applied to up to $5 \mathrm{~cm}$ tall weeds (Table 2). There was no difference between other application timings. Glyphosate/dicamba applied POST at 900, 1350, or $1800 \mathrm{~g} \cdot \mathrm{ae} \cdot \mathrm{ha}^{-1}$ advanced DR soybean maturity as indicated by seed moisture content at harvest. There was no interaction between herbicide dose and application timing for injury, seed moisture content, and yield. The authors suggest that the delayed DR soybean maturity in the untreated control and with the early application of glyphosate/dicamba 
TABLE 1: Density of weed species present at each evaluation for Ridgetown and Exeter, ON, sites.

\begin{tabular}{|c|c|c|c|c|c|c|c|c|}
\hline \multirow{2}{*}{ Weed species } & \multirow{2}{*}{ Timing } & \multicolumn{7}{|c|}{ Weed density $\left(\# \mathrm{~m}^{-2}\right)$} \\
\hline & & R-2016a & $\mathrm{R}-2016 \mathrm{~b}$ & R-2017 & E-2017 & $\mathrm{R}-2018 \mathrm{a}$ & $\mathrm{R}-2018 \mathrm{~b}$ & E-2018 \\
\hline \multirow{3}{*}{ Amaranthus spp. } & $4 \mathrm{WAA}$ & 57 & 19 & 19 & 11 & 11 & - & 6 \\
\hline & 8 WAA & 35 & 17 & 21 & 9 & 10 & - & 4 \\
\hline & $10 \mathrm{WAC}$ & 50 & 5 & 10 & 9 & 13 & - & 2 \\
\hline \multirow{3}{*}{ Ambrosia artemisiifolia } & 4 WAA & 9 & 14 & - & 12 & 54 & 23 & - \\
\hline & 8 WAA & 9 & 28 & - & 12 & 21 & 8 & - \\
\hline & $10 \mathrm{WAC}$ & 12 & 17 & - & 12 & 13 & 7 & - \\
\hline \multirow{3}{*}{ Chenopodium album } & $4 \mathrm{WAA}$ & 33 & 10 & 12 & 12 & 21 & 23 & 5 \\
\hline & 8 WAA & 30 & 25 & 14 & 12 & 15 & 13 & 3 \\
\hline & $10 \mathrm{WAC}$ & 18 & 10 & 13 & 13 & 10 & 13 & 1 \\
\hline \multirow{3}{*}{ Echinochloa crus-galli } & 4 WAA & - & - & - & 9 & - & 3 & 19 \\
\hline & 8 WAA & - & - & - & 8 & - & 7 & 12 \\
\hline & $10 \mathrm{WAC}$ & - & - & - & 8 & - & 9 & 12 \\
\hline \multirow{3}{*}{ Setaria faberi } & $4 \mathrm{WAA}$ & 99 & 114 & 70 & - & 3 & - & - \\
\hline & 8 WAA & 143 & 138 & 86 & - & 4 & - & - \\
\hline & $10 \mathrm{WAC}$ & 136 & 82 & 88 & - & 4 & - & - \\
\hline \multirow{3}{*}{ Setaria viridis } & $4 \mathrm{WAA}$ & - & - & - & 26 & 19 & 28 & 25 \\
\hline & $8 \mathrm{WAA}$ & - & - & - & 26 & 12 & 22 & 18 \\
\hline & $10 \mathrm{WAC}$ & - & - & - & 24 & 6 & 18 & 12 \\
\hline
\end{tabular}

Note. * - not present at location; E: Exeter; R: Ridgetown; WAC: weeks after final herbicide application; WAA: weeks after herbicide application.

TABLE 2: Significance of main effects and interaction for percent visible soybean injury 1 WAA, soybean moisture content at harvest, and soybean yield treated with glyphosate/dicamba at various POST application rates and timings at five Ridgetown, ON, sites (2016-2018) and two Exeter, ON, sites (2017-2018).

\begin{tabular}{|c|c|c|c|}
\hline Main effects & Injury $^{\dagger}(\%)$ & Moisture (\%) & Yield $\left(\mathrm{T} \cdot \mathrm{ha}^{-1}\right)$ \\
\hline Application timing & $* *$ & $* *$ & $*$ \\
\hline $5 \mathrm{~cm}$ weed height & $0.2^{\mathrm{a}}$ & $15.2^{\mathrm{b}}$ & $2.8^{\mathrm{b}}$ \\
\hline $15 \mathrm{~cm}$ weed height & $0.5^{\mathrm{a}}$ & $14.9^{\mathrm{ab}}$ & $3.1^{\mathrm{ab}}$ \\
\hline $25 \mathrm{~cm}$ weed height & $1.6^{\mathrm{b}}$ & $14.6^{\mathrm{a}}$ & $3.2^{\mathrm{a}}$ \\
\hline Glyphosate/dicamba rate & $* *$ & $* *$ & $* *$ \\
\hline Untreated control & $0^{\mathrm{a}}$ & $16.1^{\mathrm{b}}$ & $1.7^{\mathrm{b}}$ \\
\hline $900 \mathrm{~g} \cdot \mathrm{ae} \cdot \mathrm{ha}^{-1}$ & $0.1^{\mathrm{b}}$ & $14.6^{\mathrm{a}}$ & $3.4^{\mathrm{a}}$ \\
\hline $1350 \mathrm{~g} \cdot \mathrm{ae} \cdot \mathrm{ha}^{-1}$ & $0.7^{\mathrm{c}}$ & $14.6^{\mathrm{a}}$ & $3.5^{\mathrm{a}}$ \\
\hline $1800 \mathrm{~g} \cdot \mathrm{ae} \cdot \mathrm{ha}^{-1}$ & $1.3^{\mathrm{c}}$ & $14.5^{\mathrm{a}}$ & $3.5^{\mathrm{a}}$ \\
\hline \multicolumn{4}{|l|}{ Interaction } \\
\hline $\mathrm{R} \times \mathrm{T}$ & NS & NS & NS \\
\hline
\end{tabular}

Note. NS: not significant at $P=0.05$ level; POST: postemergence; R: herbicide rate; T: application timing; WAA: weeks after herbicide application. Means followed by the same letter within a column are not significantly different according to a Tukey-Kramer multiple range test at $P<0.05$. Differences among simple effects are not presented due to negligible $\mathrm{R} \times \mathrm{T}$ interactions. Significance at $P<0.05$ and $P<0.01$ levels denoted by ${ }^{*}$ and ${ }^{* *}$, respectively. ${ }^{\dagger}$ No soybean injury was observed at the 4 WAA evaluation.

was due to greater weed interference. Soybean yield of untreated plots was as much as $51 \%$ lower than of treated plots, probably due to weed interference (Table 2). Results are similar to Underwood [14] who found as much as $41 \%$ yield loss from weed interference in DR soybean.

\subsection{Amaranthusspp. (Green and Redroot Pigweed Combined).}

The control of Amaranthus spp. was generally lower with the early timing compared to the late timing of glyphosate/ dicamba when weeds were up to $25 \mathrm{~cm}$ tall. Glyphosate/ dicamba applied when weeds were approximately 5, 15, and $25 \mathrm{~cm}$ tall controlled Amaranthus spp. 96, 99, and 99\% at 4 WAA; 92,96 , and $99 \%$ at $8 \mathrm{WAA}$; and 87,94 , and $99 \%$ at 10 WAC, respectively (Table 3). Glyphosate/dicamba at 900,
1350, and $1800 \mathrm{~g} \cdot \mathrm{ae} \cdot \mathrm{ha}^{-1}$ controlled Amaranthus spp. 97, 98, and $99 \%$ at 4 WAA; 94,97 , and $99 \%$ at 8 WAA; and 90, 95, and $97 \%$ at $10 \mathrm{WAC}$, respectively (Table 3 ). Results are similar to Johnson et al. [15] who found near-perfect control of Amaranthus spp. with glyphosate plus dicamba in DR soybean. Underwood [14] also reported 96-98\% control of Amaranthus spp. at 2 WAA with glyphosate plus dicamba $\left(900+300 \mathrm{~g} \cdot \mathrm{ae} \cdot \mathrm{ha}^{-1}\right)$ in DR soybean.

3.3. A. artemisiifolia. The control of A. artemisiifolia tended to be generally lower with the early timing compared to the late timing of glyphosate/dicamba when weeds were up to $25 \mathrm{~cm}$ tall (Table 3). Glyphosate/dicamba applied at 5, 15, and $25 \mathrm{~cm}$ tall weeds controlled A. artemisiifolia 99, 99, and 
TABLE 3: Significance of main effects and interaction for percent visible control of Amaranthus spp., Ambrosia artemisiifolia, and Chenopodium album in soybean treated with glyphosate/dicamba at various POST timings at four Ridgetown, ON, sites (2016-2018) and two Exeter, ON, sites (2017-2018).

\begin{tabular}{|c|c|c|c|c|c|c|c|c|c|}
\hline \multirow[t]{2}{*}{ Main effects } & \multicolumn{3}{|c|}{ Amaranthus spp. control (\%) } & \multicolumn{3}{|c|}{$\begin{array}{c}\text { Ambrosia artemisiifolia } \\
\text { control (\%) }\end{array}$} & \multicolumn{3}{|c|}{ Chenopodium album control (\%) } \\
\hline & $4 \mathrm{WAA}$ & 8 WAA & $10 \mathrm{WAC}$ & 4 WAA & 8 WAA & $10 \mathrm{WAC}$ & 4 WAA & 8 WAA & $10 \mathrm{WAC}$ \\
\hline Application timing & $* *$ & $* *$ & $* *$ & NS & $*$ & $*$ & $*$ & $*$ & $* *$ \\
\hline $5 \mathrm{~cm}$ weed height & $96^{\mathrm{b}}$ & $92^{\mathrm{b}}$ & $87^{\mathrm{b}}$ & $99^{\mathrm{a}}$ & $95^{\mathrm{b}}$ & $93^{\mathrm{b}}$ & $99^{\mathrm{b}}$ & $94^{\mathrm{b}}$ & $89^{\mathrm{b}}$ \\
\hline $15 \mathrm{~cm}$ weed height & $99^{\mathrm{a}}$ & $96^{\mathrm{b}}$ & $94^{\mathrm{b}}$ & $99^{\mathrm{a}}$ & $98^{\mathrm{ab}}$ & $97^{\mathrm{ab}}$ & $100^{\mathrm{a}}$ & $96^{\mathrm{b}}$ & $95^{\mathrm{ab}}$ \\
\hline $25 \mathrm{~cm}$ weed height & $99^{\mathrm{a}}$ & $99^{\mathrm{a}}$ & $99^{\mathrm{a}}$ & $99^{\mathrm{a}}$ & $100^{\mathrm{a}}$ & $99^{\mathrm{a}}$ & $100^{\mathrm{a}}$ & $99^{\mathrm{a}}$ & $99^{\mathrm{a}}$ \\
\hline Dose & $*$ & $*$ & $*$ & $*$ & NS & NS & $*$ & NS & NS \\
\hline Untreated control & $0^{\mathrm{c}}$ & $0^{\mathrm{c}}$ & $0^{\mathrm{c}}$ & $0^{c}$ & $0^{\mathrm{b}}$ & $0^{\mathrm{b}}$ & $0 \mathrm{c}$ & $0^{\mathrm{b}}$ & $0^{\mathrm{b}}$ \\
\hline $900 \mathrm{~g} \cdot \mathrm{ae} \cdot \mathrm{ha}^{-1}$ & $97^{\mathrm{b}}$ & $94^{\mathrm{b}}$ & $90^{\mathrm{b}}$ & $98^{\mathrm{b}}$ & $96^{\mathrm{a}}$ & $95^{\mathrm{a}}$ & $99^{\mathrm{b}}$ & $94^{\mathrm{a}}$ & $92^{\mathrm{a}}$ \\
\hline $1350 \mathrm{~g} \cdot \mathrm{ae} \cdot \mathrm{ha}^{-1}$ & $98^{\mathrm{ab}}$ & $97^{\mathrm{ab}}$ & $95^{\mathrm{ab}}$ & $99^{\mathrm{ab}}$ & $98^{\mathrm{a}}$ & $97^{\mathrm{a}}$ & $100^{\mathrm{a}}$ & $97^{\mathrm{a}}$ & $95^{\mathrm{a}}$ \\
\hline $1800 \mathrm{~g} \cdot \mathrm{ae}^{\mathrm{h}} \cdot \mathrm{ha}^{-1}$ & $99^{\mathrm{a}}$ & $99^{\mathrm{a}}$ & $97^{\mathrm{a}}$ & $100^{\mathrm{a}}$ & $99^{\mathrm{a}}$ & $99^{\mathrm{a}}$ & $100^{\mathrm{a}}$ & $99^{\mathrm{a}}$ & $98^{\mathrm{a}}$ \\
\hline Interaction & & & & & & & & & \\
\hline $\mathrm{R} \times \mathrm{T}$ & NS & NS & NS & NS & NS & NS & NS & NS & NS \\
\hline
\end{tabular}

Note. NS: not significant at $P=0.05$ level; POST: postemergence; R: herbicide rate; T: application timing; WAC: weeks after final herbicide application; WAA: weeks after herbicide application. Means followed by the same letter within a column are not significantly different according to a Tukey-Kramer multiple range test at $P<0.05$. Differences among simple effects are not presented due to negligible $\mathrm{R} \times \mathrm{T}$ interactions. Significance at $P<0.05$ and $P<0.01$ levels denoted by ${ }^{*}$ and ${ }^{* *}$, respectively.

TABLE 4: Significance of main effects and interaction for percent visible control of Echinochloa crus-galli, Setaria faberi, and Setaria viridis in soybean treated with glyphosate/dicamba at various POST timings at four Ridgetown, ON, sites (2016-2018) and two Exeter, ON, sites (2017-2018).

\begin{tabular}{|c|c|c|c|c|c|c|c|c|c|}
\hline \multirow{2}{*}{ Main effects } & \multicolumn{3}{|c|}{ Echinochloa crus-galli control (\%) } & \multicolumn{3}{|c|}{ Setaria faberi control (\%) } & \multicolumn{3}{|c|}{ Setaria viridis control (\%) } \\
\hline & 4 WAA & 8 WAA & $10 \mathrm{WAC}$ & 4 WAA & 8 WAA & $10 \mathrm{WAC}$ & 4 WAA & 8 WAA & $10 \mathrm{WAC}$ \\
\hline Application timing & ** & $* *$ & $* *$ & $* *$ & $* *$ & $* *$ & $* *$ & $* *$ & $* *$ \\
\hline $5 \mathrm{~cm}$ weed height & $84^{\mathrm{b}}$ & $81^{\mathrm{b}}$ & $82^{b}$ & $90^{\mathrm{b}}$ & $51^{\mathrm{b}}$ & $37^{\mathrm{c}}$ & $94^{\mathrm{b}}$ & $96^{\mathrm{b}}$ & $95^{\mathrm{b}}$ \\
\hline $15 \mathrm{~cm}$ weed height & $95^{\mathrm{a}}$ & $94^{\mathrm{a}}$ & $96^{\mathrm{a}}$ & $98^{\mathrm{a}}$ & $80^{\mathrm{b}}$ & $77^{\mathrm{b}}$ & $99^{\mathrm{a}}$ & $99^{\mathrm{a}}$ & $99^{\mathrm{a}}$ \\
\hline $25 \mathrm{~cm}$ weed height & $96^{\mathrm{a}}$ & $97^{\mathrm{a}}$ & $96^{\mathrm{a}}$ & $100^{\mathrm{a}}$ & $99^{\mathrm{a}}$ & $99^{\mathrm{a}}$ & $100^{\mathrm{a}}$ & $100^{\mathrm{a}}$ & $99^{\mathrm{a}}$ \\
\hline Dose & $* *$ & NS & $* *$ & NS & NS & NS & $* *$ & $*$ & NS \\
\hline Untreated control & $0^{\mathcal{C}}$ & $0^{\mathrm{b}}$ & $0^{c}$ & $0^{\mathrm{b}}$ & $0^{\mathrm{b}}$ & $0^{\mathrm{b}}$ & $0^{c}$ & $0^{\mathcal{c}}$ & $0^{\mathrm{b}}$ \\
\hline $900 \mathrm{~g} \cdot \mathrm{ae} \cdot \mathrm{ha}^{-1}$ & $84^{\mathrm{b}}$ & $87^{\mathrm{a}}$ & $88^{\mathrm{b}}$ & $95^{\mathrm{a}}$ & $77^{\mathrm{a}}$ & $74^{\mathrm{a}}$ & $98^{\mathrm{b}}$ & $98^{\mathrm{b}}$ & $98^{\mathrm{a}}$ \\
\hline $1350 \mathrm{~g} \cdot \mathrm{ae} \cdot \mathrm{ha}^{-1}$ & $94^{\mathrm{a}}$ & $93^{\mathrm{a}}$ & $93^{\mathrm{ab}}$ & $97^{\mathrm{a}}$ & $80^{\mathrm{a}}$ & $75^{\mathrm{a}}$ & $99^{\mathrm{ab}}$ & $99^{\mathrm{ab}}$ & $98^{\mathrm{a}}$ \\
\hline $1800 \mathrm{~g} \cdot \mathrm{ae} \cdot \mathrm{ha}^{-1}$ & $96^{\mathrm{a}}$ & $95^{\mathrm{a}}$ & $95^{\mathrm{a}}$ & $98^{\mathrm{a}}$ & $87^{\mathrm{a}}$ & $79^{\mathrm{a}}$ & $100^{\mathrm{a}}$ & $100^{\mathrm{a}}$ & $98^{\mathrm{a}}$ \\
\hline $\begin{array}{l}\text { Interaction } \\
\mathrm{R} \times \mathrm{T}\end{array}$ & NS & NS & NS & NS & NS & NS & NS & NS & NS \\
\hline
\end{tabular}

Note. NS: not significant at $P=0.05$ level; POST: postemergence; R: herbicide rate; T: application timing; WAC: weeks after final herbicide application; WAA: weeks after herbicide application. Means followed by the same letter within a column are not significantly different according to a Tukey-Kramer multiple range test at $P<0.05$. Differences among simple effects are not presented due to negligible $\mathrm{R} \times \mathrm{T}$ interactions. Significance at $P<0.05$ and $P<0.01$ levels denoted by ${ }^{*}$ and ${ }^{* *}$, respectively.

$99 \%$ at $4 \mathrm{WAA} ; 95,98$, and $100 \%$ at $8 \mathrm{WAA}$; and 93,97 , and $99 \%$ at $10 \mathrm{WAC}$, respectively (Table 3 ). Glyphosate/dicamba applied POST at 900, 1350, and $1800 \mathrm{~g} \cdot \mathrm{ae} \cdot \mathrm{ha}^{-1}$ controlled $A$. artemisiifolia 98,99 , and $100 \%$ at 4 WAA; 96,98 , and $99 \%$ at 8 WAA; and 95, 97, and 99\% at 10 WAC, respectively (Table 3). Results from this study are similar to Breitenbach et al. [16] who reported up to $99 \%$ control of A. artemisiifolia with glyphosate/dicamba in DR soybean in Minnesota, USA. Additionally, Underwood [14] reported that glyphosate plus dicamba $\left(900+300 \mathrm{~g} \cdot \mathrm{ae} \cdot \mathrm{ha}^{-1}\right)$ controlled A. artemisiifolia $98-100 \%$ in DR soybean.

3.4. C. album. The control of C. album was generally lower with the early timing compared to the late timing of glyphosate/dicamba when weeds were up to $25 \mathrm{~cm}$ tall.
Glyphosate/dicamba applied POST at up to 5, 15, and $25 \mathrm{~cm}$ tall weeds controlled C. album 99, 100, and $100 \%$ at 4 WAA; 94,96 , and $99 \%$ at $8 \mathrm{WAA}$; and 89,95 , and $99 \%$ at $10 \mathrm{WAC}$, respectively (Table 3). Glyphosate/dicamba applied POST at 900, 1350, and $1800 \mathrm{~g} \cdot \mathrm{ae} \cdot \mathrm{ha}^{-1}$ controlled C. album 99, 100, and $100 \%$ at $4 \mathrm{WAA} ; 94,97$, and $99 \%$ at $8 \mathrm{WAA}$; and 92,95 , and $98 \%$ at 10 WAC, respectively (Table 3). Similar to this study, Breitenbach et al. [16] reported up to $99 \%$ control of C. album with glyphosate + dicamba in DR soybean in Rochester, MN.

3.5. E. crus-galli. The control of E. crus-galli was significantly lower when glyphosate/dicamba was applied up to $5 \mathrm{~cm}$ tall weeds compared to 15 and $25 \mathrm{~cm}$ tall weeds (Table 4). Glyphosate/dicamba applied at application timing of up to 5, 
15 , and $25 \mathrm{~cm}$ tall weeds controlled E. crus-galli 84,95 , and $96 \%$ at $4 \mathrm{WAA} ; 81,94$, and $97 \%$ at $8 \mathrm{WAA}$; and 82,96 , and $96 \%$ at 10 WAC, respectively (Table 4). E. crus-galli control generally increased as the dose of the glyphosate/dicamba was increased. Glyphosate/dicamba applied POST at 900, 1350, and $1800 \mathrm{~g} \cdot \mathrm{ae} \cdot \mathrm{ha}^{-1}$ controlled E. crus-galli 84, 94, and $96 \%$ at 4 WAA; 87,93 , and $95 \%$ at 8 WAA; and 88,93 , and $95 \%$ at $10 \mathrm{WAC}$, respectively (Table 4 ). In other studies, Breitenbach et al. [16] reported 98, 97, 97, and 94\% control of grass species with glyphosate/dicamba applied early POST in DR soybean in Rochester, MN. Additionally, Underwood [14] reported that glyphosate plus dicamba $\left(900+300 \mathrm{~g} \cdot \mathrm{ae} \cdot \mathrm{ha}^{-1}\right)$ controlled E. crus-galli as much as $99 \%$ in DR soybean.

3.6. S. faberi. The control of S. faberi with glyphosate/ dicamba tended to generally increase as the application timing was delayed (Table 4). Glyphosate/dicamba applied at up to 5,15 , and $25 \mathrm{~cm}$ tall weeds controlled $S$. faberi 90,98 , and $100 \%$ at $4 \mathrm{WAA} ; 51,80$, and $99 \%$ at $8 \mathrm{WAA}$; and 37,77 , and $99 \%$ at $10 \mathrm{WAC}$, respectively (Table 3 ). There was no appreciable influence of the application dose of glyphosate/ dicamba on the control of S. faberi (Table 4). Glyphosate/ dicamba applied POST at 900, 1350, and $1800 \mathrm{~g} \cdot \mathrm{ae} \cdot \mathrm{ha}^{-1}$ controlled S. faberi 95,97 , and $98 \%$ at $4 \mathrm{WAA} ; 77,80$, and $87 \%$ at $8 \mathrm{WAA}$; and 74,75 , and $79 \%$ at $10 \mathrm{WAC}$, respectively (Table 4).

3.7. S. viridis. The control of $S$. viridis with glyphosate/ dicamba was higher when the timing was delayed (Table 4). Glyphosate/dicamba applied at application timing of up to 5, 15 , and $25 \mathrm{~cm}$ tall weeds controlled S. viridis 94, 99, and $100 \%$ at $4 \mathrm{WAA} ; 96,99$, and $100 \%$ at $8 \mathrm{WAA}$; and 95,99 , and $99 \%$ at 10 WAC, respectively (Table 4). There was no appreciable influence of the application dose of glyphosate/ dicamba on the control of $S$. viridis (Table 4). Glyphosate/ dicamba applied POST at 900, 1350, and $1800 \mathrm{~g} \cdot \mathrm{ae} \cdot \mathrm{ha}^{-1}$ controlled S. viridis 98,99 , and $100 \%$ at $4 \mathrm{WAA} ; 98,99$, and $100 \%$ at $8 \mathrm{WAA}$; and 98,98 , and $98 \%$ at $10 \mathrm{WAC}$, respectively (Table 4). Similar to this study, Underwood [14] reported that glyphosate plus dicamba $\left(900+300 \mathrm{~g} \cdot \mathrm{ae} \cdot \mathrm{ha}^{-1}\right)$ controlled S. viridis $93-97 \%$ in DR soybean.

\section{Conclusions}

Based on these results, glyphosate/dicamba applied postemergence at 900, 1350, and $1800 \mathrm{~g} \cdot \mathrm{ae} \cdot \mathrm{ha}^{-1}$ causes minimal injury in DR soybean. Presumed weed interference delayed DR soybean maturity and reduced DR soybean yield as much as $51 \%$. There was an increase in DR soybean yield with the application of glyphosate/dicamba, but there was no difference in yield among application doses. DR soybean yield was lower with the early application of glyphosate/ dicamba; the authors suggest that this was due to increased weed emergence and interference after the early application. There was a trend for increased weed control as the glyphosate/dicamba dose was increased and the application timing was delayed. Based on these results, glyphosate/ dicamba at the manufacturer's label doses adequately controls C. album, Amaranthus spp., A. artemisiifolia, S. faberi, S. viridis, and E. crus-galli in DR soybean. Weed control was generally least consistent with E. crus-galli and S. faberi especially when glyphosate/dicamba was applied at the lowest registered dose $\left(900 \mathrm{~g} \cdot \mathrm{ae} \cdot \mathrm{ha}^{-1}\right)$ and when these weeds were up to $5 \mathrm{~cm}$ tall. Weed control was generally most consistent when glyphosate/dicamba was applied at the highest registered dose in Ontario (1800 g.ae.ha ${ }^{-1}$ ) and when weeds were up to $25 \mathrm{~cm}$ tall. However, to reduce injury in neighbouring sensitive crops from the off-target movement of dicamba, it is recommended that glyphosate/dicamba be applied early in the season, preferably before sensitive crops emerge in adjacent fields. Long-term stewardship of the DR soybean technology is critical to minimize injury in sensitive crops due to off-target movement in adjacent fields and ensure that this valuable technology is available for the control of multiple-resistant weed biotypes.

\section{Data Availability}

The numerical data used to generate tables in this manuscript can be provided upon request to the authors.

\section{Conflicts of Interest}

The authors declare that they have no conflicts of interest.

\section{Acknowledgments}

Financial support for this study came from the Grain Farmers of Ontario.

\section{References}

[1] H. P. Byker, N. Soltani, D. E. Robinson, F. J. Tardif, M. B. Lawton, and P. H. Sikkema, "Control of glyphosateresistant horseweed (Conyza canadensis) with dicamba applied preplant and postemergence in dicamba-resistant soybean," Weed Technology, vol. 27, no. 3, pp. 492-496, 2013.

[2] M. G. Schryver, N. Soltani, D. C. Hooker, D. E. Robinson, P. J. Tranel, and P. H. Sikkema, "Glyphosate-resistant waterhemp (Amaranthus tuberculatus var. rudis) in Ontario, Canada," Canadian Journal of Plant Science, vol. 97, pp. 1057-1067, 2017.

[3] A. C. Van Wely, "Distribution and control of glyphosateresistant common ragweed (Ambrosia artemisiifolia L.) in Ontario," pp. 1-121, Thesis, University of Guelph, Guelph, Canada, 2015.

[4] B. K. Hedges, N. Soltani, D. E. Robinson, D. C. Hooker, and P. H. Sikkema, "Influence of glyphosate/dicamba application rate and timing on the control of glyphosate-resistant waterhemp in glyphosate/dicamba-resistant soybean," $\mathrm{Ca}$ nadian Journal of Plant Science, vol. 99, no. 3, pp. 371-374, 2019.

[5] J. P. Vink, N. Soltani, D. E. Robinson, F. J. Tardif, M. B. Lawton, and P. H. Sikkema, "Glyphosate-resistant giant ragweed (Ambrosia trifida) control in dicamba-tolerant soybean," Weed Technology, vol. 26, no. 3, pp. 422-428, 2012.

[6] A. C. Rojas Ariasa, J. L. Palacio, A. Chaparro-Giraldo, and S. A. López-Pazosb, "Patents and genetically modified soybean 
for glyphosate resistance," World Patent Information, vol. 48, pp. $47-51,2017$.

[7] I. Heap, "The international survey of herbicide resistant weeds," 2019, http://www.weedscience.org.

[8] D. J. Spaunhorst and K. W. Bradley, "Influence of dicamba and dicamba plus glyphosate combinations on the control of glyphosate-resistant waterhemp (Amaranthus rudis)," Weed Technology, vol. 27, no. 4, pp. 675-681, 2013.

[9] D. J. Spaunhorst, S. Siefert-Higgins, and K. W. Bradley, "Glyphosate-resistant giant ragweed (Ambrosia trifida) and waterhemp (Amaranthus rudis) management in dicambaresistant soybean (Glycine max)," Weed Technology, vol. 28, no. 1, pp. 131-141, 2014.

[10] [OMAFRA] Ontario Ministry of Agriculture, Food and Rural Affairs, Area, Yield, Production and Farm Value of Specified Field Crops (Imperial and Metric Units), Ontario of Agriculture, Food and Rural Affairs, Guelph, Canada, 2019, http:// www.omafra.gov.on.ca/english/stats/crops/index.html.

[11] D. L. Shaner, Herbicide Handbook, Weed Science Society of America, Champaign, IL, USA, 10th edition, 2014.

[12] [SAS] Institute Inc., SAS/STAT ${ }^{\circledR} 12.3$ User's Guide, Base SAS ${ }^{\circledR}$ 9.4 Procedures Guide: Statistical Procedures, SAS Institute Inc., Cary, NC, USA, 5th edition, 2013.

[13] A. R. Kniss, "Soybean response to dicamba: a meta-analysis," Weed Technology, vol. 32, no. 5, pp. 507-512, 2018.

[14] M. G. Underwood, Determining the Fit of Dicamba-Resistant Soybean for Ontario Agriculture, M.Sc. thesis, p. 143, 2017, https://atrium.lib.uoguelph.ca/xmlui/bitstream/handle/10214/ 12130/Underwood_Matthew_201801_Msc.pdf?sequence= 1 \&isAllowed $=\mathrm{y}$.

[15] B. Johnson, B. Young, J. Matthews et al., "Weed control in dicamba-resistant soybeans," Crop Management, vol. 9, no. 1, pp. 00, 2010, http://www.plantmanagementnetwork.org.

[16] F. R. Breitenbach, L. M. Behnken, R. Searcy, and A. Kyllo, Evaluation of A21472 for weed control in RR2-XTEND soybeans at Rochester, MN in 2016, University of Minnesota, Rochester, MN, USA, 2016, https://appliedweeds.cfans.umn. edu/sites/appliedweeds.cfans.umn.edu/files/16soy08.pdf. 